\title{
Lessons Learned and Present Prospects: A Critical Review of Agricultural Education in Thailand ${ }^{1}$
}

\author{
Dr. Pongpan Traimongkolkul \\ Associate Professor \\ Agricultural and Environmental Education Program \\ Kasetsart University, Kampaengsaen Campus \\ Nakhon Pathom 73140, Thailand \\ E-mail: feduppt@,ku.ac.th \\ Dr. Prasong Tanpichai \\ Assistant Professor \\ Agricultural and Environmental Education Program \\ Kasetsart University, Thailand \\ E-mail: fedupst@ku.ac.th
}

\begin{abstract}
Thailand is a leading food exporter in Southeast Asia. Over a century of development, agricultural education has been instrumental to agricultural development of the country. With the on-going movements in educational reform and renewed direction of agricultural development, there is a need to holistically examine the system of agricultural education in Thailand.

This nationwide study reviewed the past and examined the present prospects of agricultural education at three levels: basic education, vocational education, and higher education. The research methods include an extensive documentary analysis, an empirical analysis with surveys and case studies, and reflections from opinion leaders.

Inspired by the US land-grant model, the contemporary era of agricultural education in Thailand began in 1943 with an establishment of the first university specialized in agriculture. Stimulated by the green revolution of the 1960s and 1970s, agricultural education during that period expanded rapidly to meet the nation's demand for manpower and technology. Aside from the success on this primary role, critics have pinpointed the side effects of agricultural education on small-scale farmers.

Strength of the Thai system of agricultural education lies in its comprehensive and diversified structure, a result of resource accumulation over the booming period. At present, the existing system is being questioned on its relevance. Higher education in agriculture, being the spearhead of the system, has been a subject of criticism on "functional imbalance."

To be relevant, agricultural education must be more responsive to the changing contexts of national development, keeping equilibrium of competitiveness and sustainability of Thai agriculture. It is imperative that a national forum on agricultural education must be formed, serving as a task force to revitalize the total system of agricultural education. Recommendations are given for strengthening of agricultural education at all levels. Enhancing the linkage between formal and non-formal education is also recommended.
\end{abstract}

Keywords: Agricultural Education, Agricultural Development, Educational Policy, Thailand

1 Acknowledgment: This research was supported by the Thailand Research Fund.

Fall 2005 


\section{Introduction}

Over the past four decades, agricultural growth in Asia has been dramatic as a result of the Green Revolution rushing into the region during the 1960s and 1970s. The Asian developing countries in particular have experienced a rapid expansion in agricultural exports since the mid-1970s (Itagaki, 1999). However, in this present period of post-green revolution, progress on biological technology, increasing pressure on environmental problems, and high competition in international trade, altogether have a major impact on agricultural system of Asian developing countries.

Given the challenging milieu of tomorrow, agriculture and agricultural education in Asia needs to be redefined and revolutionized. In regional forums, reengineering of the agricultural education system has been echoed, and new models of agricultural education are sought for better functioning in a wider parameter of multifunctional agriculture (Mancebo et al., 2002). In so-doing, there is an urgent need for the region to "diagnose the root problems of the system, examine its strengths and weaknesses and project a future scenario to develop/or improve a responsive agriculture education system." (Mancebo, 1999).

The food-production cluster is significant to the Thai economy. Agricultural production and related industries contribute to over 50 per cent of the nation's economy (Falvey, 2000). Since the nation's first commencement on social and economic development plan (19581964), agricultural development has continued to rank in the top priority of national policy. Although economic growth has been increasingly significant in the industrial sector over the recent decade, agriculture remains an important part of the national economy and the Thai culture.

Along the road to "modernization," the major economic crisis of 1997 evidently stirred up an intense awareness of critical problems that have accumulated from the four decades of mainstream path to development. Lending his thought to alleviate the crisis, King Bhumibhol issued his prominent philosophy of "sufficient economy," calling for the nation to seek alternative approaches to development, with the goal of self-reliance, a balance of social and economic sustainability and contentedness. The King's philosophy has been well received by policy makers, academic professionals, and concerned development agents, prompting an agenda on a balanced direction of national development.

Following the King's noble advice, there was a felt need for rethinking of the country's direction in agriculture. As a consequence, the latest national plan for agricultural development (2002-2006) has thus shifted emphasis from development that relies solely on the mainstream agriculture to a more balanced "dualistic approach" of Thai agriculture. Under this renewed direction, there is competitive "exportoriented" agriculture on one side, and "sufficient agriculture" for small-scale farmers on the other (Ministry of Agriculture, 2002).

Reviewing the past developments of Thai agriculture, Lindsey Falvey, a regional expert on agricultural development, noted that the future of Thai agriculture depends on its quality of education, general as well as agricultural education (Falvey, 2000). Agricultural education must therefore be reoriented to serve the future direction of Thai agriculture.

Beginning in the year 1999, Thailand has embarked on a holistic educational reform. To achieve the goal of this reform, policy research is needed in all areas of education to elicit information required for strategic planning. Perceiving the significant role of agricultural education in fostering agricultural development, the Thailand Research Fund (TRF) initiated a nationwide study entitled "A Critical Review: Status and Prospects of Agricultural Education in 
Thailand." Aiming for policy implications, the study examined holistically the system of agricultural education in Thailand.

\section{Purpose and Objectives}

The purpose of this research was to review the status and prospects of agricultural education in Thailand. The endresult was policy recommendations for agricultural education that is responsive to the changing contexts of national development. The objectives were:

1. Review historical developments of agricultural education in Thailand, and to determine factors associated with the past developments as well as the lessons learned.

2. Examine the current status and prospects of agricultural education in Thailand.
Methods

Agricultural education in this study refers to formal education in agriculture delivered at three levels; namely, basic education, vocational education, and higher (tertiary) education. The study was conducted during the years 2003-2004. The research process consisted of three consecutive steps. Extensive documentary analyses set the stage for subsequent indepth empirical analysis. Reflective accounts, secured from opinion leaders, further enriched the findings (Figure 1).

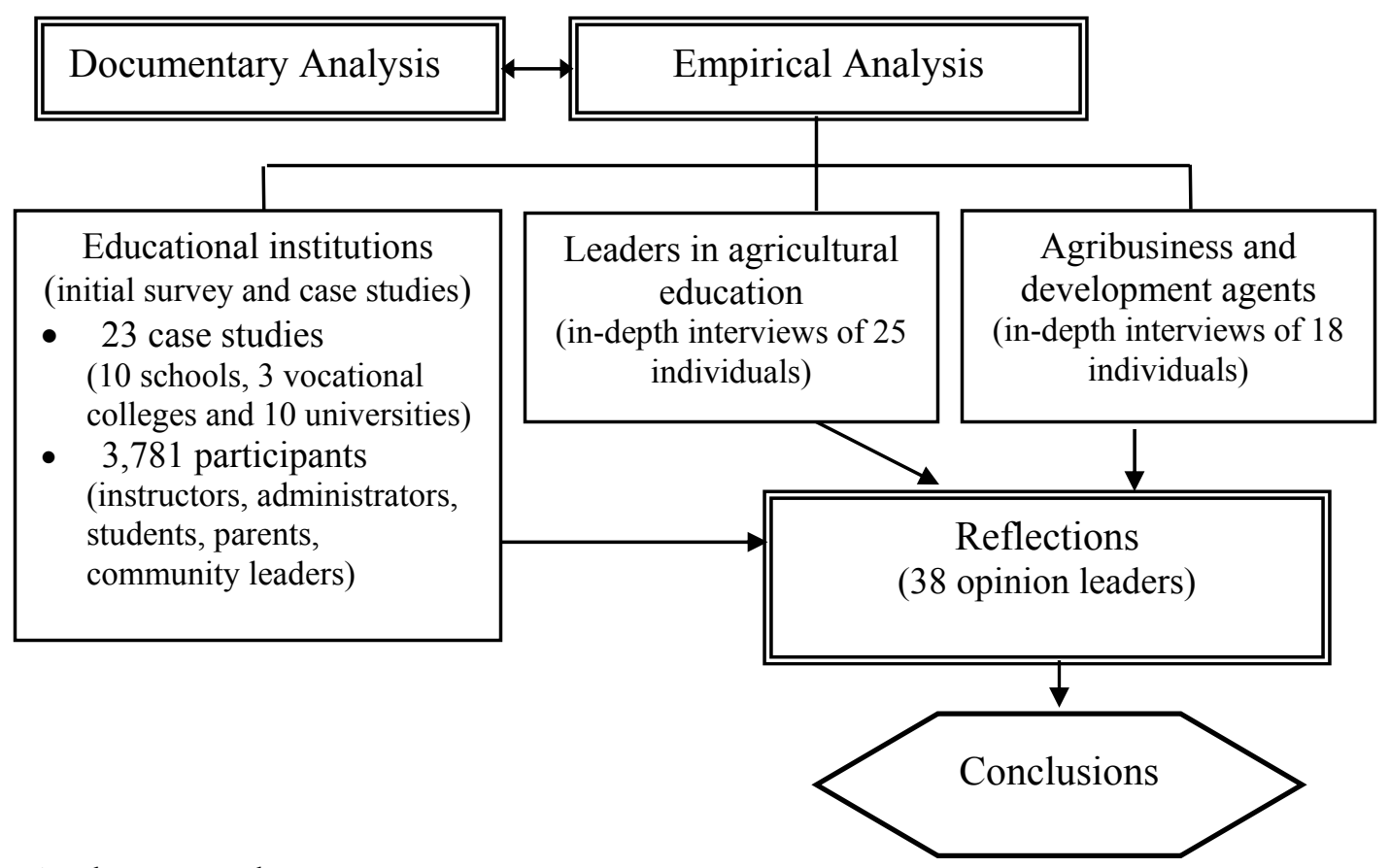

Figure 1. The research process. 
Each step of the research process is described as follows:

\section{Documentary Analysis}

Documents on past developments of agricultural education were extensively reviewed, dating back to the 1950s period when the country opened up for a "modernized" approach to national development. Documents on the current prospects of agricultural education were further reviewed. The documents consisted of policy and plans issued by the government, historical accounts, research reports, philosophical and concept writings, secondary sources of statistical data, and international documents available on the Internet. Content analysis was performed on the documents.

Empirical Analysis

Findings on status and prospects of agricultural education were obtained through the following methods:

Initial survey. An institutional survey was conducted to obtain an overview of current status from organizations/institutions in charge of providing education in agriculture. Information was collected first from the available Internet sources, followed by mail and telephone correspondence. Brief descriptive data on existing educational programs were obtained from college deans of agriculture in 10 public universities, directors of 3 vocational colleges of agriculture, and the head of information services in the Ministry of Education. In addition to primary data, secondary data were extensively obtained at this stage. Providing wide-angle information, the survey was helpful in the further refinement of research questions and selection of key informants as well as case studies.

Interviews of key informants. Indepth interviews were conducted from 43 leaders in agricultural education, agricultural development and agricultural business. Identification of key informants was achieved from the initial survey together with snowball sampling. Direct contact of the researchers with the respondents allows meaningful dialogues, assuring richness and validity of data.

Case studies. Twenty-three case studies of schools and educational institutions were secured from in-depth field study by the researchers. Using a multicase/multi-site approach, the 23 cases were purposively selected, yielding diversified samples of 10 schools, 3 vocational colleges in agriculture, and 10 universities. To maximize sample diversification, the following criteria were used: 1) school educational level, affiliation, size, and type; and 2) affiliation, development level, and structure of colleges and universities.

Both researchers were directly involved in the actual field study of all 23 cases. A multi-methods approach was employed for data collection in each case study, as follows:

1. In-depth interviews of instructors, administrators, parents and community members, local wisdom farmers, and engaged educational researchers.

2. On-site observations of agricultural activities in the sample schools, vocational colleges, and universities.

Documents on curricula and agriculture programs were also collected.

3. Attitude surveys of students at each level, supplemented with individual/ group interviews of selected students.

Methods of triangulation provided a validity check for results from each case study. A total of 3,781 participants took part in the case studies, providing information in one way or another. Data from case studies were analyzed with content analysis and descriptive statistics. 
Reflections from Opinion Leaders

A forum of 39 opinion leaders was conducted in order to secure reflections on preliminary research findings of this study, and for the participants to share their thoughts on policy implications. The opinion leaders were purposively selected from all parties concerned: agricultural educators, local wisdom teachers, agricultural business, and government as well as non-government leaders in agricultural development. Some of the opinion leaders were selected during the interviews with key informants. The others were identified from consultations with key personnel in each sector.

\section{Findings and Discussion}

Historical Profile of Agricultural Education in Thailand

Basic Education in Agriculture. Over a century ago, dating back to the year 1898 , formal agricultural education was first established in primary schools under the provision of compulsory education. Basic education in agriculture began with school gardening in elementary schools for the purpose of orienting students with fundamental agricultural knowledge and practices as a way of life. Notably, specialized schools were set up for training of agriculture teachers to carry out the teaching of agriculture in elementary schools. However, the teacher-training project was ceased after a decade due to an abrupt change in educational policy as well as budget limitations.

Later developments of basic education in agriculture were mostly influenced by the U.S concept of agricultural education. Among the most prominent is the "comprehensive school" model, which was implemented in secondary schools in 1967. Once again, the project was short-life due to a subsequent change in educational policy.

Vocational education in agriculture. Extending from the early vocational education delivered in primary and secondary schools, vocational education in agriculture was later delivered in specialized vocational colleges of agriculture. The 1970 s was considered the "high time" of vocational education in agriculture with a rapid proliferation of agricultural colleges in response to high demand for vocational manpower in the government sector. The three corner stones of vocational agriculture "classroom teaching-learning, an organization for students (FFA), and supervised agricultural experience" have been adopted as a core model for Thai vocational agriculture with the mixed outcomes of success and failure.

Higher education in agriculture. Inspired by the US land-grant model, contemporary era of agricultural education in Thailand began in 1943 with an establishment of the first university specialized in agriculture. Stimulated by the green revolution of the 1960s and 1970s, agricultural education during that period expanded rapidly to meet the nation's demand for manpower and technology.

The past two decades saw a proliferation of public universities offering programs in agricultural sciences and related disciplines. The programs vary distinctively according to the background of universities, grouped into 3 categories: the existing comprehensive universities, newly up-lifted universities with vocational foundation, and newly up-lifted universities with teacher training foundation. Presently, nearly all of the total 74 universities offer programs in agriculture or related sciences.

Over the past 100 years, agricultural education has evolved with noted policy fluctuations. Significant factors contributing to past developments are: 1) vision of the fore-founders and supportive political wills; 2 ) the green revolution movement in the region during 1960s and 1970s; and 3) international supports, heavily influenced by the United States of America. Table 1 summarizes the development path of agricultural education in Thailand. 
Table 1

Major Developmental Periods of Thai Agricultural Education

\begin{tabular}{ll}
\hline Years and Periods & Description \\
\hline 1898: Formative & $\begin{array}{l}\text { Following the compulsory education mandated in 1898, formal } \\
\text { education in agriculture was first established in primary schools. } \\
\text { Agriculture teacher training was initiated. }\end{array}$ \\
1960: Green Revolution & $\begin{array}{l}\text { Agricultural education, especially at higher level, was boosted by the } \\
\text { demand for manpower and technology to meet the green revolution. } \\
\text { The U.S. model of agricultural education was adopted. }\end{array}$ \\
& $\begin{array}{l}\text { Unfocused expansion of vocational and higher education in } \\
\text { agriculture in expectation of manpower demand by the government } \\
\text { sector. }\end{array}$ \\
& $\begin{array}{l}\text { Agricultural education under pressure to change influenced by the } \\
\text { country's holistic reform in education and renewed direction in } \\
\text { agricultural development. }\end{array}$ \\
\hline
\end{tabular}

Impact of Agricultural Education

Primary Impact: Development of

Human Resources and Technology. Impact

of the green revolution on Asian agriculture located in Monsoon areas has been well documented (Itagaki, 1999). In the case of Thailand, the green revolution rushing into the country during the 1960s and 1970s changed the face of Thai agriculture from subsistent farming to commercial/exportoriented agriculture. Agricultural education has been instrumental to the country's agricultural development by "producing people to produce technology," contributing significantly to the success of Thailand as a leading food exporter of Asia.

Secondary Impact: Social Aspects of Mainstream Development. With exception of Japan and South Korea, agricultural colleges and universities in Asia were originally inspired by the U.S. land-grant model with the trilogy of mission - teaching, research, and outreach/extension. In a review of agricultural colleges and universities in Asia, Bernado (1985) pointed out that attempting to adopt the land-grant mission resulted in varying degrees of success. A considerable success was noted in the case of India. In most other cases, the coordination of research and extension was hindered by the country's organization structure carrying the mission in agricultural development. Another UNESCO regional survey revealed that much of the information generated from research by universities and colleges did not reach the intended users, primary the farmers (Saguiguit, 1987).

A similar scenario was observed in the case of Thailand. As respondents in this study, senior professors from leading colleges of agriculture recalled the strong orientation of the land-grant mission in the establishment of the first agricultural university. One prominent professor noted: In Thailand, research and extension in agriculture is the responsibility of Ministry of Agriculture. Unlike in the U.S. system, there is no effective linkage between colleges of agriculture and the ministry to cooperatively carry out the functions. So, as time goes by, we [college professors] tend to lose our sense of research-extension mission.

Outreach is a university function expected most by small-scale farmers. When colleges of agriculture cannot fully meet 
such expectations, the issue of educational relevance is often raised. Local wisdom farmers and NGO workers likewise echoed the question of "agricultural education for whom?" Cited below are some of the reflections secured in this research:

"From the first National Education Plan [1960], the university people have produced personnel and technology to serve primarily the demand of agribusiness rather than the needs of small-scale farmers."

"The gap between the rich big farmers/agribusiness and the smallscale farmers are more and more widened."

"Shifting to commercial agriculture, small-scale farmers have lost the love of land together with the sense of selfdependency."

The cited comments center on the issues of equity and access to agricultural development, an often cited secondary consequence of the past green revolution (Jit-sanguan et al, 2001). GDP alone is not accepted as a valid indicator of development. Using SDI (Sustainable Development Indicator) in his analysis, UanSakul (2000) concluded that the decade of development prior to the 1997 economic crisis in Thailand did not contribute substantially to the uplifting of farmers' quality of life and sustainability of environment. On the contrary, over the 35 years of the past 7 national development plans, a gap in income distribution between agricultural and non-agricultural sectors jumped from a ratio of 1:6 to $1: 13$. This wide gap is an indicator of adverse impact of agricultural development on the agricultural population, particularly the small-scale farmers.

A principal consequence of development programs on small-scale farmers has received much attention in the recent years. But is agricultural education to blame? "There are various factors involved in the sustainability and well-beings of farmers. Why should agricultural education be the culprit after all?," asked some respondents from colleges of agriculture. To the same question, local wisdom farmers had this to say:

"Who have benefited most from our agricultural education? Surely, not the majority farmers. Agricultural education has not been responsive to our real needs..."

"What is taught in schools and colleges is not relevant to the reality of Thai agriculture and Thai farmers."

The dilemma of educational relevance may be viewed differently from another angle. Key informants in the agribusiness sector admitted that agricultural education has contributed greatly to the growth of agribusiness in Thailand since the 1970s. However, at present teaching and research in colleges of agriculture do not link well with what exist in reality. In their opinion, graduates today are not adequately prepared for the world of work in Thai agriculture, let alone to be part of competitive agribusiness on an international scale.

In sum, the impact of agricultural education thus far has been evident on development of human resources and technology. The social impact-responding to the needs of the agricultural population, is much in question.

\section{Status and Prospects}

The existing system of Thai agricultural education is described at three levels. Basic education in agriculture. At basic level, agricultural education is included in the general education curriculum for grade 1 to 12 students. As part of the existing educational reform, a new curriculum for basic education was implemented in 2001 with more emphasis given to academic subjects in the expense of 
time allotted for vocational subjects such as agriculture.

On a positive side, within the realm of the on-going educational reform, exemplary cases of school agricultural programs could be identified from documentary sources and field data in this study. Eight illustrative cases were grouped as follows: 1) active learning through agriculture-based integrated curriculum;2) agricultural activities for the socially/economically disadvantaged learners in rural areas; and 3) sustainable agricultural projects nurtured by external supports.

Success factors identified from these cases were: 1) school readiness, with committed agriculture teachers and supportive administrator, 2) community support from the school board, parents, community leaders, and local wisdom farmers, and 3) external inputs in funding and other supports provided by various parties involved.

Contrary to the positive cases, irrelevant and non-stimulating agricultural education characterized the more typical scenarios found in this study. Constraints in such cases were attributed mainly to schoollimiting factors and lack of support for agricultural learning resources. New problems also emerged, associated with weak links in the recent curricular reform with more emphasis in general "academic" education, resembling the "return-to-the basics" phenomenon.

Table 2

Strengths and Weaknesses of Basic Education in Agriculture

\begin{tabular}{|c|c|}
\hline Strengths/Opportunities & Weaknesses/Constraints \\
\hline $\begin{array}{l}\text { - The current movements in learning reform } \\
\text { encourage a favorable environment for } \\
\text { relevant agricultural education. } \\
\text { - Design of community-based curriculum in } \\
\text { agriculture } \\
\text { - Involvement of community members, } \\
\text { especially local wisdom in agriculture } \\
\text { - Local network for learning, actively } \\
\text { stimulated by government and non- } \\
\text { government organizations }\end{array}$ & $\begin{array}{l}\text { - Limitations hindered by the curriculum } \\
\text { reform } \\
\text { - An orientation toward "return-to-the } \\
\text { basics." Agricultural education in the new } \\
\text { curriculum is reduced. } \\
\text { - Weak mechanism at school level to assist } \\
\text { teachers in management of school-based } \\
\text { curriculum that is relevant to the } \\
\text { community needs } \\
\text { - School-limiting factors: } \\
\text { o Lack of well-trained agriculture } \\
\text { teachers and adequate learning } \\
\text { resources } \\
\text { o low attention/support from school } \\
\text { administrators }\end{array}$ \\
\hline
\end{tabular}

Vocational education in agriculture. In Thailand, vocational education in agriculture is delivered primarily in 45 vocational colleges specialized in agriculture. Expansion of these colleges was the result of the proliferation during the 1970s and 1980s. Following the saturation of manpower in the government sector, the high time of vocational education in agriculture has passed. Vocational colleges of agriculture today are facing critical problems of declining enrollment and subsequent budget shortfalls. However, with their potential of reaching local clientele, vocational colleges of agriculture have played a key role in providing educational opportunity for the lower population of youth, mostly from the agricultural sector. Falling enrollment has lead to a poor profile of entering students, and 
subsequently a low funded budget. As an alternative for existence, these colleges have broadened their service area, extending to the more promising vocational programs such as business administration and computer education. In this regard, vocational colleges of agriculture are gradually moving away from its agricultural specialization, turning toward comprehensive vocational/technical education without adequate resources. This trend will have an adverse impact on future development of most colleges of vocational agriculture and the nation's vocational manpower in agriculture.

\section{Table 3}

Strengths and Weaknesses of Vocational Education in Agriculture

\begin{tabular}{ll}
\hline Strengths/Opportunities & Weaknesses/Constraints \\
\hline - $\begin{array}{l}\text { Sound philosophical basis in vocational } \\
\text { agriculture }\end{array}$ & $\begin{array}{l}\text { Limited learning resources, a consequence } \\
\text { of the unfocused proliferation. }\end{array}$ \\
- $\begin{array}{l}\text { Good educational infrastructure, } \\
\text { accumulated from past developments to } \\
\text { sustain vocational programs in agriculture }\end{array}$ & $\begin{array}{l}\text { Poor profile of entering students } \\
\text { (quantity/quality) }\end{array}$ \\
- $\begin{array}{l}\text { Strong tradition in community outreach } \\
\text { and experiences to cope with new areas of }\end{array}$ & $\begin{array}{l}\text { education in agriculture } \\
\text { Unfocused direction, a result of expanding }\end{array}$ \\
& service areas to non-agriculture programs \\
\hline
\end{tabular}

Higher education in agriculture. Of the 74 public universities in Thailand, 24 established universities offer academicoriented programs in agricultural sciences. Most of the other uplifted universities offer practical-based programs. Analysis of higher education in agriculture reveals the following issues.

Program diversity versus quality standard. Programs in agricultural sciences were characterized by diversity among universities with different foundations and different stages of development as previously mentioned. The strength of such diversity is the potential of higher education to meet the demands of a wide-range clientele and in technology development/adaptations at various levels of use. However, concern was raised among the university respondents on the issue of the quality standard - competition is more evident on quantity, less on quality.

Significant constraints. The major constraints facing higher education in agriculture were identified. First, despite the proliferation of degree programs offered by universities, declining interest in the conventional agricultural sciences has been evident in the recent decade. This subsequently leads to a decrease in number and quality of students entering agricultural programs. The problem is more critical in less prominent universities where dropout rate has increased each year. Secondly, there is an observable decline in the quantity and quality of professional resources, a task force needed to carry further the educational mission. As a case in point, the coming decade will see a loss of critical mass, up to $30-50 \%$ of senior professors in major universities, due to retirement. Only partial substitution is anticipated. Thirdly, universities are under increasing pressure to become more self-reliant, following the government policy on public university autonomy. Anticipation of financial tightness has lead to a widespread commercialization of agricultural programs, a move toward the "market-driven model." Extra income is also a major incentive for many faculty members to move into this direction. Key informants in this study 
expressed their concern that this trend would have a significant impact on the equity and opportunity of prospective students, especially for the lower population. Loosened sense of mission. In principle, most universities with colleges/programs in agriculture shared a common guiding philosophy based on the US land-grant mission. In practice, however, the sense of mission has evidently deteriorated. The trend has much in common with the market-driven dilemma facing the US land-grant institutions (Hutchinson \& Elliot, 2004).
Table 4 summarizes strengths and weaknesses of the existing system of higher education in agriculture. From dialogues with the research participants and opinion leaders, it was evident that agricultural professionals perceived the aforementioned pertinent problems. Several solutions were explored through academic forums in recent years. However, strategic movements were lacking in adapting to the rapidly changing circumstances. Colleges of agriculture in leading universities, the corpus of the system, have not taken adequate initiatives in reform movements.

\section{Table 4}

Strengths and Weaknesses of Higher Education in Agriculture

\begin{tabular}{|c|c|}
\hline Strengths/Opportunities & Weaknesses/Constraints \\
\hline $\begin{array}{l}\text { - Sound philosophical foundation; guiding } \\
\text { the mission on teaching, research and } \\
\text { outreach, inspired by the US land-grant } \\
\text { model } \\
\text { - Quality of existing resources in the well- } \\
\text { established universities, serving as the } \\
\text { nucleus for development of the more } \\
\text { recent universities } \\
\text { Diversity of programs in agricultural } \\
\text { sciences serving the varying needs of } \\
\text { manpower and technology development. }\end{array}$ & $\begin{array}{l}\text { - Diversity in program quality caused } \\
\text { primarily by unfocused proliferation of } \\
\text { universities/degree programs in } \\
\text { agriculture } \\
\text { - Anticipation of budget shortfalls leading } \\
\text { to: } \\
\text { o Widespread commercialization in } \\
\text { agricultural education } \\
\text { o Decrease in the equity of access to } \\
\text { higher education of the disadvantaged } \\
\text { population, especially farmer youths. } \\
\text { o Functional imbalance, particularly on } \\
\text { the sense of mission. }\end{array}$ \\
\hline
\end{tabular}

\section{Conclusions}

At the reflection forum of this study, the opinion leaders arrived at this conclusion: the new paradigm of Thai agricultural development has set the stage for alternative models of agricultural education. On the contrary, the system of agricultural education itself is still attached to the conventional rigid model of education.

Agricultural education worldwide shares the common "gloomy picture" of such problems as steady erosion of attention from policy-makers; declining enrollments; deteriorating infrastructure, unemployment of graduates, a changing profile of students/trainees (Maguire, 1999). This holistic study revealed that the system of agricultural education in Thailand is experiencing a similar problematic scenario, and that provocative movement is lacking.

\section{Looking Ahead: Policy Implications} Education for the Future of Thai Agriculture The strength of the Thai economy lies in the potential of its food production cluster. For a country with a distinctively dualistic society and economy, three dimensions of agricultural development must be considered holistically. These are agriculture for sustainable Thai society, agriculture for a sustainable economy, and 
agriculture for a sustainable environment. In line with the recently established national plan for agricultural development, a dualistic approach of agricultural development is therefore reiterated:

- Agriculture for competitiveness. To be more competitive, export-oriented agriculture must be strengthened with the balance of economic and environmental sustainability.

- Agriculture for sustainability of the Thai dualistic society. Based on the lessons learned, agricultural development must sustain an equilibrium of "globalizationlocalization," and "economic returns" of large-scale farmers, versus self-sufficiency" of smallholder farmers

To be more responsive to this bilateral direction, agricultural education needs to be bi-functional, sustaining a well balance of academic and social relevance.

\section{Recommendations}

A concerted effort from the agricultural education community is needed in moving agricultural education forward. Two levels of recommendations are proposed herewith. At macro level: An "agricultural education forum" should be established. This task force of the professionals in agricultural education should assume the following responsibility:

1. Formulation of a national plan for agricultural education. Pertinent research and activities are needed to provide support for this prospective master plan. Some proposals are:

A. Formulation of an operational plan of dualistic agricultural development. Active involvement is needed from agricultural educators, policy makers, private sectors, farmers, and government/non-government development personnel.

B. Analysis of manpower demands in agriculture leading to a master plan of manpower supply in the agricultural sector.

C. Unit-cost analysis of educational programs focusing on vocational and higher level of education in agriculture. The analysis will provide baseline data for budgeting.

2. Formulation of a strategic plan for agricultural education. A set of policy measures and key performance indicators should be defined.

3. Determination of key channels and mechanisms for mobilizing the plan into action.

At micro/institutional level: Strengthening of formal agricultural education is recommended at every level, as follows:

Basic education. Agricultural education must be adapted to the new curricular structure. Through universityschool networking, model curricular/model schools can be initiated for integration of agricultural content in other subject areas reflecting the variety of programs relevant to community contexts and needs of students. More support should be rendered for school programs that help to empower the disadvantaged population in rural areas. Emphasis should be placed more on the process of active learning such as good working habits rather than the outputs in farm products and income.

Vocational education. Expanding the service areas to non-agriculture programs must be carefully considered while maintaining the strength of the existing agriculture-based vocational colleges. To better function under increasingly limited resources, regional clustering of vocational colleges of agriculture is strongly recommended. The notion of a local-based center of excellence should be mobilized based on the strength of each existing college. More emphasis should be placed on an effective networking channel of serving 
the local clientele. Through academic initiatives such as small-scale and localbased R\&D projects, community-based learning can be enhanced while meeting the real needs of the community.

Higher education. Well-established colleges of agriculture in major universities should take the lead in reforming the degree programs in agricultural sciences to be more responsive to the needs of the society. Keeping the "balance" is the key concept, some of which are suggested below:

Balance of mission (teaching, research and outreach). A strong sense of mission must be enhanced in the system of professional promotion and rewarding for faculty members. Viable linkage with Ministry of Agriculture must be strengthened in research and extension, particularly when dealing with small-scale farmers.

Balance of disciplinary orientation. For agricultural sciences to be most relevant to the needs of the country, balance in the content must be considered in such aspects as "specialized/integrated knowledge," "import-based technology/local-based technology," "mainstream agriculture/alternative agriculture," and "conventional agriculture/hybrid agriculture." To reinforce the balance, restructuring of academic units and innovative design of curriculum are needed. Funding for research projects must also take into consideration the balance of disciplinary orientation.

Balance of program diversity and

quality. A quality forum should be set up to establish and foresee guiding principles and minimum standards to be imposed on degree curricula. The standards, however, should allow flexibility for program diversity among universities with different backgrounds.

Balance of "academic/socialdriven" and "market-driven" models of education. The proposed quality forum should assume an active role keeping the balance on this aspect. Restructuring of resource management is needed for rendering quality programs. Furthermore, the profession must communicate explicitly to policy makers that higher education in agriculture runs the risk of losing the balance if unit-cost budgeting is strictly imposed without appropriate measures.

Balance of competition-cooperation. Horizontal as well as vertical networking of educational institutions should be strongly encouraged with a viable implementing channel. Area-based networking of institutions should be strengthened. In addition to strengthening of formal education, enhancing linkage between formal and non-formal education is strongly recommended. Meaningful experiential learning for college students and faculty can be achieved through problem-based academic activities that link theory to practical reality of Thai agriculture. The activities can be blended into a compulsory component of degree program. In addition, a sense of social service can be enforced through small-scale interdisciplinary activities reaching target farmers and the local food industrial cluster. Networking between vocational colleges of agriculture and community colleges must be enhanced.

A detailed framework of policy strategies, with corresponding measures, was proposed in the full report of this research. To encourage further action, the full report was submitted to the National Council of College Deans in Agriculture.

\section{References}

Bernado, F. A. (1985). Status, constraints, and challenges of education at agricultural colleges and universities. Proceedings of the Symposium on Education for Agriculture, Manila, Philippines, 27-36.

Falvey, L. (2000). Thai agriculture: Golden cradle of millennia. Bangkok: Kasetsart University Press. 
Hutchinson, B., \& Elliot, J. (2004). In a market-driven high-tech world, is the land-grant model still viable? Proceedings of the $20^{\text {th }}$ Annual Conference, Association for International Agricultural and Extension Education, Dublin, Ireland, 962. Retrieved June 2005, from http://www.aiaee.org/2004/carousels/ hutchinson-carousel-NEW.pdf

Itagaki, K. (1999). Agricultural performance and human resources development. In Trends and perspectives in agricultural education in AsiaPacific (pp. 103-121). Report of the APO Symposium on Agricultural Education System, Tokyo. Tokyo: Asian Productivity Organization.

Jit-sanguan, T., Sookkamnerd, D., \& Limsomboonchai, W. (2001). Report of the project on strategies and policy on sustainable agricultural development. Kasetsart University, Bangkok, Thailand.

Mancebo, S. (1999). Agriculture system in Asia: Issues for the future. In Trends and perspectives in agricultural education in Asia-Pacific (pp. 156170). Report of the APO Symposium on Agricultural Education System, Tokyo. Tokyo: Asian Productivity Organization.
Mancebo, S., Perlas, M., \& Tuquero, F. (Eds.). (2002). Searching for new models of agriculture education in a disturbed environment. Proceedings of the $1^{\text {st }}$ International Conference on Agriculture and Environment, Los Banos, Phillippines: The International Rice Research Institute.

Mcguire, C. (1999). Future prospects for agricultural education systems. In Trends and perspectives in agricultural education in AsiaPacific (pp. 141-155).Report of the APO Symposium on Agricultural Education System, Tokyo. Tokyo: Asian Productivity Organization.

Ministry of Agriculture and Cooperatives. (2002). The national agricultural development plan (2002-2007). Ministry of Agriculture and Cooperatives, Bangkok, Thailand.

Saguiguit, Jr., G. C. (1987). Higher education in agriculture and rural development. Bangkok: UNESCO Regional Office for Education in Asia and the Pacific.

Uan-sakul, A. (2000). Sustainable agricultural development: Approach and Indicator. Proceedings of the $1^{\text {st }}$ National Agricultural System, Bangkok, Thailand, 31-49. 